\title{
Zooplankton composition and distribution off the coast of Galicia, Spain
}

\author{
J.L.Valdes, M.R.Roman ${ }^{1}$, M.T.Alvarez-Ossorio, A.L.Gauzens ${ }^{1}$ and \\ A.Miranda ${ }^{2}$ \\ Instituto Español de Oceanografia, PO Box 130, La Coruña, Spain, ${ }^{1}$ Horn Point \\ Laboratories, University of Maryland, PO Box 775, Cambridge, MD 21613, \\ USA and ${ }^{2}$ Instituto Español de Oceanografia, PO Box 1552, Vigo, Spain
}

\begin{abstract}
During June and September 1984, zooplankton samples were collected with other hydrographic and biological data along the Galician coast (NW of Spain). In June copepods contributed $\sim 60 \%$ to the total zooplankton community, with larvaceans, siphonophores and cladocerans also abundant. In September $>90 \%$ of the zooplankton sampled were copepods. The dominant species of copepods in both June and September were Acartia clausi, Paracalanus parvus and Temora longicornis. The meroplankton was dominated by echinoderms, bryozoans, barnacle larvae and bivalve larvae. In June the average zooplankton biomass was $31.08 \mathrm{mg} \mathrm{C} \mathrm{m}^{-3}$; the September average was $41.69 \mathrm{mg} \mathrm{C} \mathrm{m}^{-3}$. The relationship between the slopes of the regression equations (biomass versus abundance) suggests that the zooplankton assemblage in June was composed by larger animals than in September. The major concentration of zooplankton was between 0 and $50 \mathrm{~m}$, with both June and September daytime surface samples having 6-7 times the amount of organisms than the lower water column $(50-100 \mathrm{~m})$. There were no distinct differences in total zooplankton abundances at the inshore and offshore stations; however, the inshore stations often had a higher percentage of meroplankton than the offshore stations. In June zooplankton abundance at the northern transects and the western transects was similar. In September there were greater concentrations of zooplankton in the western Galician shelf as compared with the northern shelf. These differences in the horizontal distribution of the zooplankton were related to upwelling events.
\end{abstract}

\section{Introduction}

The Galician coast is situated on the NW Iberian Peninsula (Figure 1). It is of particular oceanographic interest due to upwelling processes associated with the North Atlantic anticyclonic gyre and the presence of the Rias Bajas, which are tectonic drowned valleys with positive estuarine circulation (Otto, 1975; Fraga, 1981). The enrichment of nutrients in the surface waters produced by upwelling and the influence of the Rias, have made this area into a productive fisheries region. For example, catches of sardines (Sardina pilchardus) exceed 100000 metric tons per year in the Galician and Cantabrican coast. The annual aquaculture production of mussels (Mytilus edulis) in the Rias is $120000-$ 145000 metric tons (Perez and Roman, 1979).

Given the economic importance of the fishery and the aquaculture industries in this area, both the Rias Bajas and the shelf have been the object of physical (Fraga, 1967, 1981; Gomez-Gallego, 1971, 1975; Fraga et al., 1982; Blanton et al., 1982) and biological studies (Margalef et al., 1955; Spohr and Corral, 1976; Alcaraz, 1977; Estrada, 1984). However, only recently have there been multidisciplinary studies that relate oceanographic conditions to pelagic and demersal fisheries both on the continental shelf and the Rias (Tenore et al., 1982). 


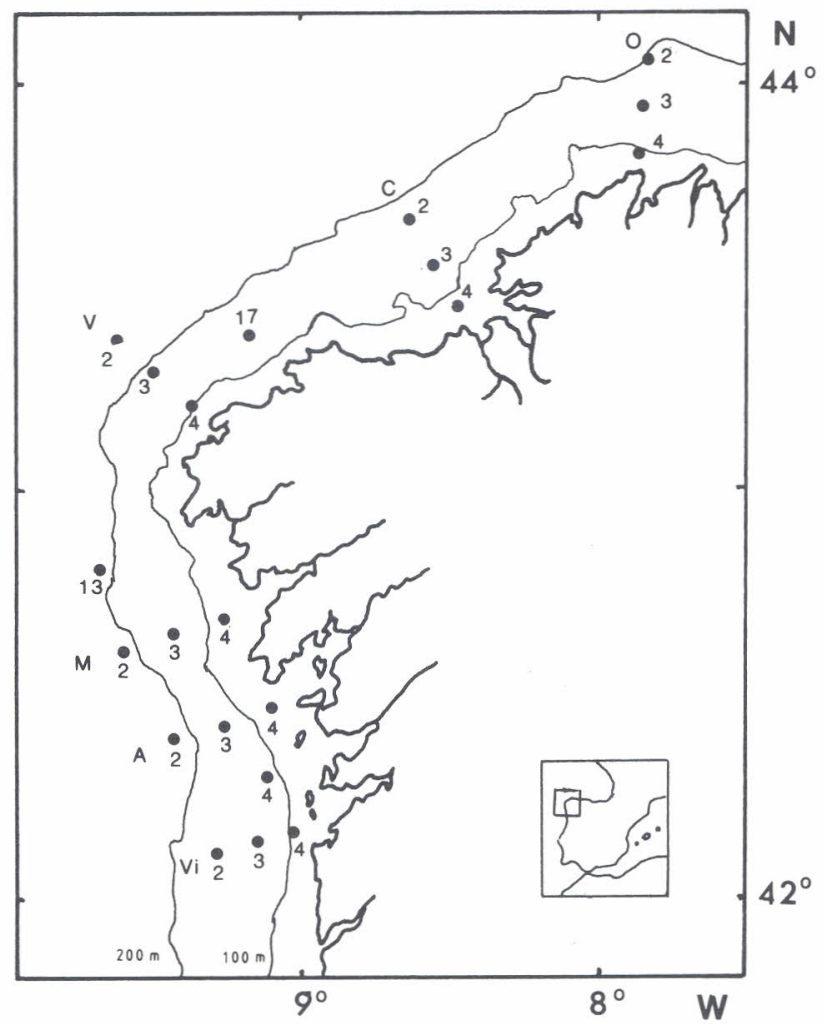

Fig. 1. Study area, showing station locations.

The zooplankton in both the Rias (Spohr and Corral, 1976; Alcaraz, 1977; Alvarez-Ossorio, 1977; Corral and Alvarez-Ossorio, 1978) and on the continental shelf (Lakkis, 1967; Alvarez-Ossorio, 1984) have been the object of several studies. The annual cycle of zooplankton abundance is typical of temperate areas with two maxima, one in the spring and one in the autumn. The distribution and composition of zooplankton are influenced both by upwelling on the shelf and by outflow from the Rias Bajas. While copepods dominate the zooplankton assemblage, at certain times of the year meroplankton from the Rias constitute a significant portion of the zooplankton community (Corral and Alvarez-Ossorio, 1978).

In this paper we analyzed the distribution and composition of zooplankton during cruises BREOGAN 684 (June, 1984) and 984 (September, 1984) from 22 stations (Figure 1) along the Galician coast.

During cruise BREOGAN 684, winds blowing from the NE resulted in upwelling events localized at Cape Ortegal and Finisterre (35.6\%o salinity and $13^{\circ} \mathrm{C}$ temperature in the sea-surface near the coast) and to a lesser extent to the south of the Rias Bajas. During most of cruise BREOGAN 984, winds blew from the SSW and were not favorable for upwelling. At the end of the cruise the
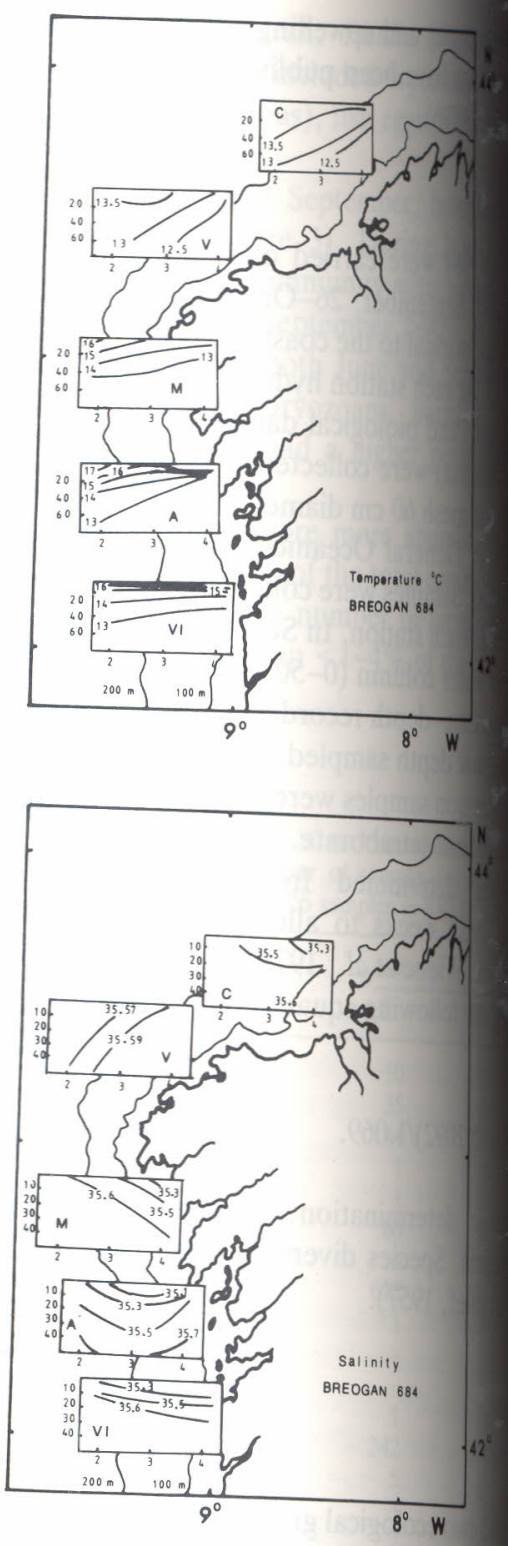

Fig. 2. Vertical distribution of temperatur BREOGAN 984. Depth in $\mathrm{m}$, Temperature if

winds shifted to the WNW and September, upwelling was apparent Ria de Vigo $\left(13.6^{\circ} \mathrm{C}\right.$ sea-surface temp The intensity of upwelling decreased offshore (Figure 2). 

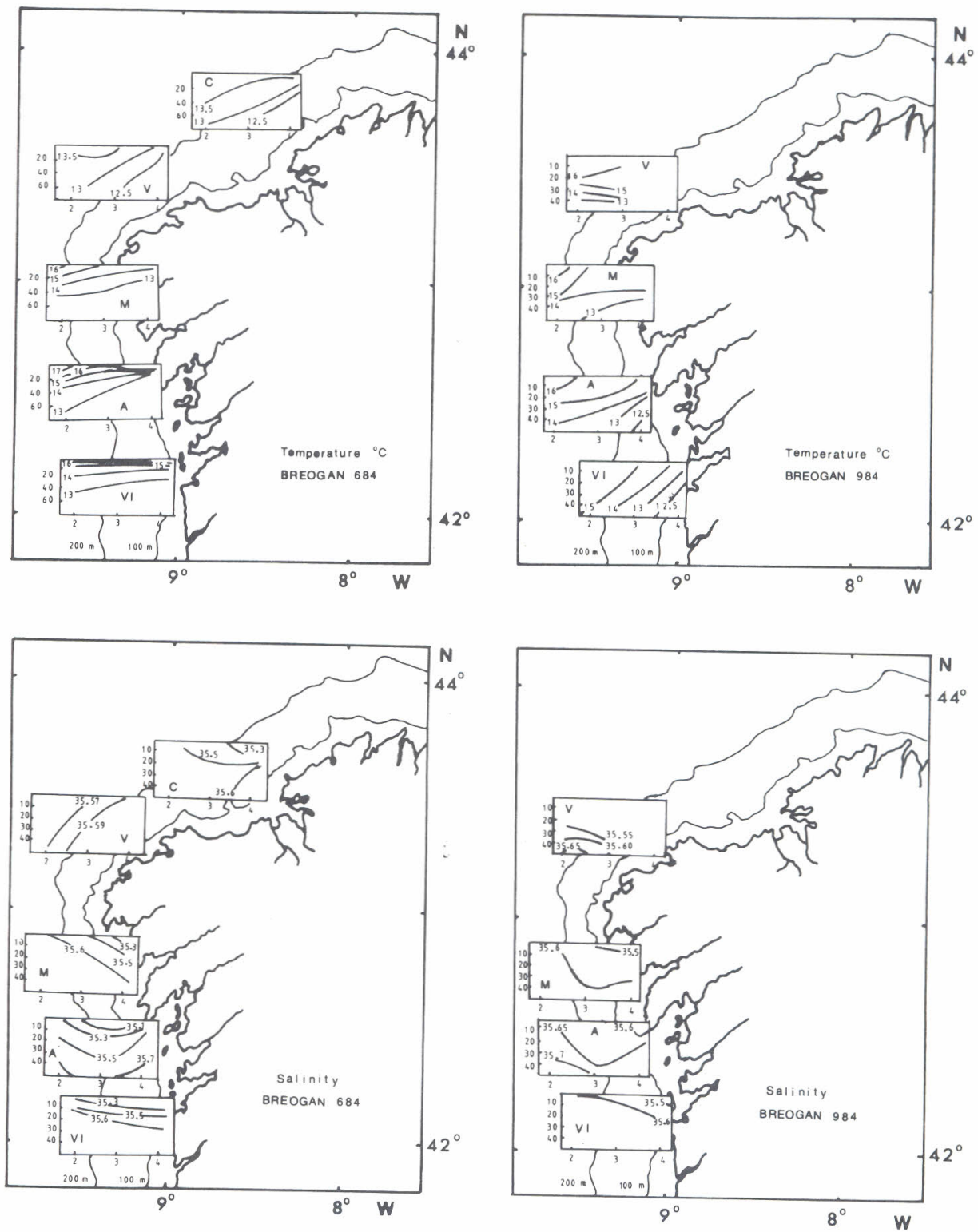

Fig. 2. Vertical distribution of temperature and salinity in the cruises BREOGAN 684 and BREOGAN 984. Depth in $\mathrm{m}$, Temperature in ${ }^{\circ} \mathrm{C}$, salinity in $\%$.

winds shifted to the WNW and were slightly favorable to upwelling. In September, upwelling was apparent only to the south of the Rias Bajas at the Ria de Vigo $\left(13.6^{\circ} \mathrm{C}\right.$ sea-surface temperature and $50 \mu \mathrm{g}$ at $\mathrm{N}-\mathrm{NO}_{3} \mathrm{l}^{-1}$ at $\left.15 \mathrm{~m}\right)$. The intensity of upwelling decreased gradually towards the north of the Rias and offshore (Figure 2). 
Studies of the descriptive physical oceanography and upwelling intensity, and a description of the phytoplankton in this area have been published elsewhere (McClain et al., 1986; Varela et al., 1987a, 1987b).

\section{Materials and methods}

Cruises BREOGAN 684 and BREOGAN 984 were carried out on the R/V Cornide Saavedra (June 7-23, 1984 and September 26-October 2, 1984 respectively). A series of stations were made normal to the coastline both to the North and West of Cape Vilano (Figure 1). At each station hydrographical data (temperature, salinity, nutrients and oxygen) and biological data (phytoplankton, zooplankton, ichthyoplankton and bacteria) were collected.

Zooplankton were sampled with a $202 \mu \mathrm{m}$ mesh $60 \mathrm{~cm}$ diameter opening and closing net towed between 1 and $1.5 \mathrm{kn}$. A General Oceanics flowmeter was used to determine the water volume sampled. Samples were collected in oblique tows from 0 to $50 \mathrm{~m}$ and from 50 to $100 \mathrm{~m}$ at each station. In September, due to the loss of one of the nets, only the upper water column $(0-50 \mathrm{~m})$ was sampled at Vilano, Coruña and Ortegal. A benthos time-depth recorder was positioned near the bottom net to determine the deepest depth sampled. All zooplankton tows were collected during the day. Zooplankton samples were preserved in $4 \%$ formalin and buffered to a $\mathrm{pH}$ of 8 with sodium tetraborate.

Non-gelatinous plankton biomass was determined from displacement volumes. Preserved samples were held for 6 weeks to allow for maximum shrinkage due to the effects of the formalin (Wiebe et al., 1975). Displacement volume was converted to $\mathrm{mg} \mathrm{C} \mathrm{m}^{-3}$ using the following equation (Roman et al., 1985):

$$
\log C=(\log \mathrm{DV}+2.2092) / 1.069 \text {. }
$$

Subsamples were taken for taxonomic determination. Organisms were identified to the species level when possible. Species diversity was calculated using the Shanon-Weaver equation (Margalef, 1957).

\section{Results and discussion}

\section{Composition}

We have divided the zooplankton data into two ecological groups: holoplankton and meroplankton. The holoplankton include foraminifera, medusae, siphonophores, pteropods, polychaetes (Tomopteris sp.), cladocerans, ostracods (Conchoecia curta) and copepods. Thirty-six species of adult copepods were identified. There were also many copepodites and nauplii present but we could not identify them to species. Additional holoplankton included amphipods, isopods, euphasiids (calyptopis and furcilia stages), chaetognaths (Sagitta spp.), larvaceans (Oikopleura spp.) and salps.

Within the meroplankton we found molluscs (gastropod and bivalve veliger), polychaetes (mainly Spionidae), barnacle larvae (cyprid and nauplii) and crab zoeae (anomuran, Pisidia lon meroplankton included bryozo: and ophiopluteus), fish eggs ( I).

In June and September, ho sampled (Figure 3). During Jur zooplankton community with la abundant. In September $>909$ (Figure 3). In both June and S echinoderms, bryozoans, barn stations often had a higher per stations.

Larvaceans were more abund from $<1$ to $53 \%$ of the total comr $\mathrm{SD}=374)$. The number of larv and only made up $<1-4 \%$ of the $\mathrm{m}^{-3}, \mathrm{SD}=30$ ).

Table I. Mean $(\bar{X})$ in $\mathrm{N} \mathrm{m}^{-3}$ and standard considering the number of samples $(n)$ BREOGAN 684 and 26 samples in BREOC

\begin{tabular}{lll}
\hline \multicolumn{6}{l}{684} & \\
\cline { 2 - 3 } & $\bar{X}$ & s
\end{tabular}

Foraminifera

Hydromedusae

Siphonophora

Polychaeta

Heteropoda

Cladocera

Ostracoda

Copepoda

Amphipoda

Mysidacea

Isopoda

Chaetognatha

Appendicularia

Doliolida

Salpida

Polychaeta larvae

Gastropoda larvae

Bivalvia larvae

Cirripedia larvae

Euphausiacea larvae

Brachyura larvae

Anomura larvae

Bryozoa larvae

Echinodermata larvae

Fish eggs

Fish larvae

Others larvae

$\begin{array}{rr}10 & 12 \\ 35 & 36 \\ 144 & 139 \\ 1 & 1 \\ 1 & - \\ 80 & 94 \\ - & - \\ 672 & 641 \\ 1 & - \\ - & - \\ - & \\ 1 & 1 \\ 242 & 374 \\ 5 & 5 \\ 3 & 3 \\ 7 & 12 \\ 11 & 20 \\ 5 & 9 \\ 9 & 11 \\ 11 & 14 \\ 2 & 2 \\ 2 & 0 \\ 8 & 9 \\ 69 & 188 \\ 3 & 3 \\ 2 & 1 \\ 5 & 4\end{array}$


zoeae (anomuran, Pisidia longicornis; brachyuran and others). Additional meroplankton included bryozoans (cyphonautes), echinoderms (echinopluteus and ophiopluteus), fish eggs (mainly Sardina pilchardus) and fish larvae (Table I).

In June and September, holoplankton averaged 95\% of the zooplankton sampled (Figure 3). During June copepods contributed $\sim 64 \%$ to the total zooplankton community with larvaceans, siphonophores and cladocerans also abundant. In September $>90 \%$ of the zooplankton sampled were copepods (Figure 3). In both June and September the meroplankton was dominated by echinoderms, bryozoans, barnacle larvae and bivalve larvae. The inshore stations often had a higher percentage of these organisms than the offshore stations.

Larvaceans were more abundant in June than in September. They ranged from $<1$ to $53 \%$ of the total community with an average of $14 \%$ (242 ind. $\mathrm{m}^{-3}$, $\mathrm{SD}=374)$. The number of larvaceans diminished significantly by September and only made up $<1-4 \%$ of the zooplankton with an average of $1 \%$ (27 ind. $\left.\mathrm{m}^{-3}, \mathrm{SD}=30\right)$.

Table I. Mean $(\bar{X})$ in $\mathrm{N} \mathrm{m}^{-3}$ and standard deviation (SD) of the zooplankton groups, calculated considering the number of samples $(n)$ in which they occurred from a total of 24 samples in BREOGAN 684 and 26 samples in BREOGAN 984

\begin{tabular}{|c|c|c|c|c|c|c|}
\hline & \multicolumn{3}{|l|}{684} & \multicolumn{3}{|l|}{984} \\
\hline & $\bar{X}$ & $\mathrm{SD}$ & $n$ & $\bar{X}$ & $\mathrm{SD}$ & $n$ \\
\hline Foraminifera & 10 & $12:$ & 7 & 10 & 13 & 8 \\
\hline Hydromedusae & 35 & 36 & 9 & 5 & 7 & 7 \\
\hline Siphonophora & 144 & 139 & 24 & 21 & 26 & 19 \\
\hline Polychaeta & 1 & 1 & 6 & - & - & - \\
\hline Heteropoda & 1 & - & 1 & - & - & - \\
\hline Cladocera & 80 & 94 & 21 & 36 & 51 & 18 \\
\hline Ostracoda & - & - & - & 11 & - & 1 \\
\hline Copepoda & 672 & 641 & 24 & 3330 & 3016 & 26 \\
\hline Amphipoda & 1 & - & 1 & 4 & 2 & 6 \\
\hline Mysidacea & - & - & - & 1 & 1 & 4 \\
\hline Isopoda & - & - & - & 1 & - & 1 \\
\hline Chaetognatha & 1 & 1 & 4 & 5 & 5 & 19 \\
\hline Appendicularia & 242 & 374 & 23 & 27 & 30 & 25 \\
\hline Doliolida & 5 & 5 & 13 & - & - & - \\
\hline Salpida & 3 & 3 & 5 & - & - & - \\
\hline Polychaeta larvae & 7 & 12 & 20 & 3 & 2 & 9 \\
\hline Gastropoda larvae & 11 & 20 & 20 & 11 & 11 & 23 \\
\hline Bivalvia larvae & 5 & 9 & 16 & 37 & 64 & 21 \\
\hline Cirripedia larvae & 9 & 11 & 19 & 19 & 36 & 20 \\
\hline Euphausiacea larvae & 11 & 14 & 21 & 38 & 43 & 25 \\
\hline Brachyura larvae & 2 & 2 & 11 & 4 & 2 & 5 \\
\hline Anomura larvae & 2 & 0 & 2 & 4 & 2 & 7 \\
\hline Bryozoa larvae & 8 & 9 & 18 & 58 & 65 & 25 \\
\hline Echinodermata larvae & 69 & 188 & 15 & 5 & 4 & 8 \\
\hline Fish eggs & 3 & 3 & 5 & 5 & 3 & 3 \\
\hline Fish larvae & 2 & 1 & 4 & 1 & 0 & 3 \\
\hline Others larvae & 5 & 4 & 21 & 7 & 6 & 12 \\
\hline
\end{tabular}




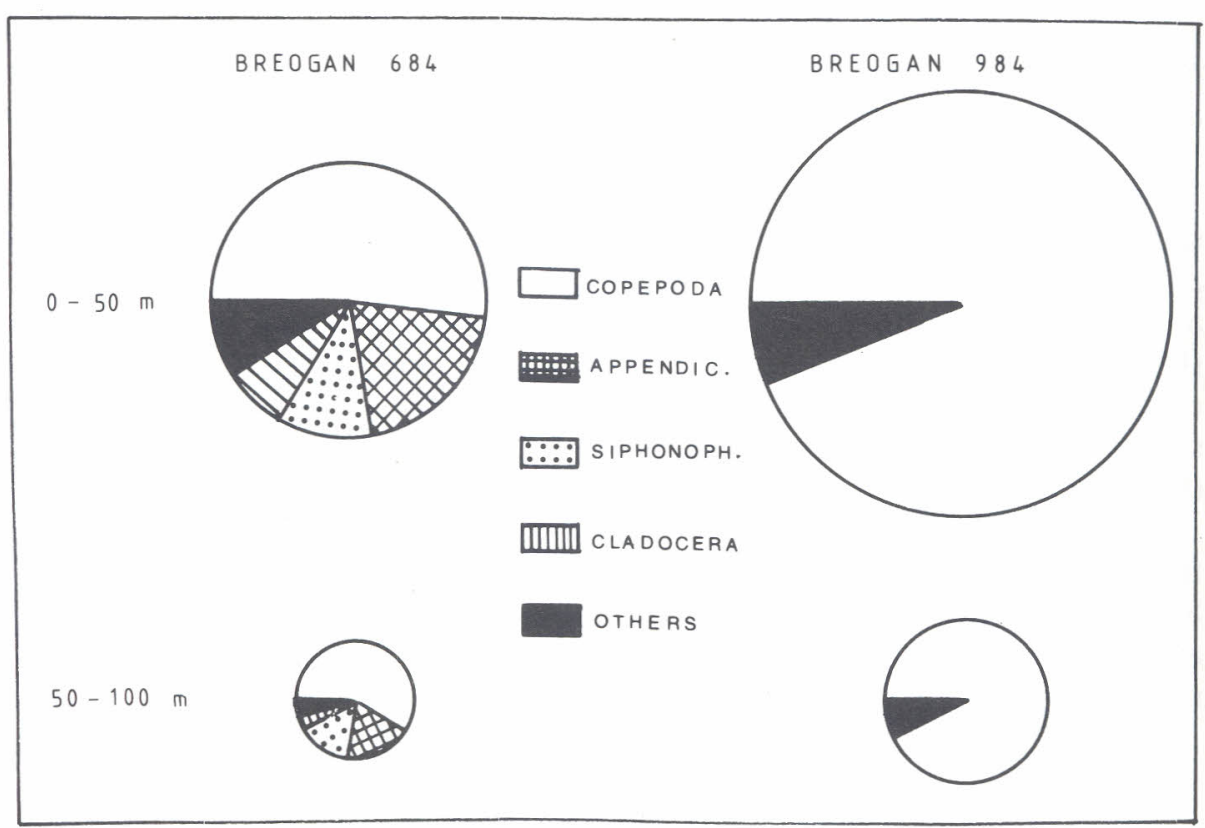

Fig. 3. Main per cent composition of selected zooplankton categories for both cruises and depths. Circle areas are proportional to abundance.

Gelatinous zooplankton (medusae, siphonophores, salps and doliolids) made up $15 \%$ of the zooplankton community in June and $1 \%$ in September. The siphonophores were the most numerically abundant of the gelatinous zooplankton. The per cent composition of these organisms at all stations ranged from $<1$ to $37 \%$ in June with an average of $12 \%\left(144\right.$ ind. $\left.\mathrm{m}^{-3}, \mathrm{SD}=139\right)$. In September their per cent composition range was only $<1-6 \%$ with an average of $1 \%\left(21\right.$ ind. $\left.\mathrm{m}^{-3}, \mathrm{SD}=26\right)$.

Cladocerans were represented by three species: Podon intermedius, Evadne nordmanni and E.spinifera. This group accounted for 5\% of the zooplankters (80 ind. $\mathrm{m}^{-3}, \mathrm{SD}=94$ ) in June with a range of $<1-32 \%$. In September the cladoceran per cent composition range was $<1-10 \%$ with an average of $1 \%$ (36 ind. $\mathrm{m}^{-3}, \mathrm{SD}=51$ ).

In June copepods and larvaceans were the dominant zooplankton component $\left(>200\right.$ ind $\left.\mathrm{m}^{-3}\right)$. The second most abundant groups comprised of the siphonophores, cladocerans and echinoderm larvae $\left(>20-200\right.$ ind $\left.\mathrm{m}^{-3}\right)$. In September copepods were the dominant group $\left(>200\right.$ ind $\left.\mathrm{m}^{-3}\right)$. Bryozoans, euphausiid larvae, bivalve larvae, larvaceans and cladocerans comprised the second most abundant group of animals (>20-200 ind. $\mathrm{m}^{-3}$ ) (Figure 4).

The abundance of copepods relative to the total amount of zooplankton increased from June to September. In June their per cent composition ranged from 29 to $92 \%$ with an average of $64 \%$ (672 ind. $\left.\mathrm{m}^{-3}, \mathrm{SD}=641\right)$. In September the range was $64-99 \%$ with an average of $92 \%$ (3330 ind. $\left.\mathrm{m}^{-3}, \mathrm{SD}=3016\right)$.

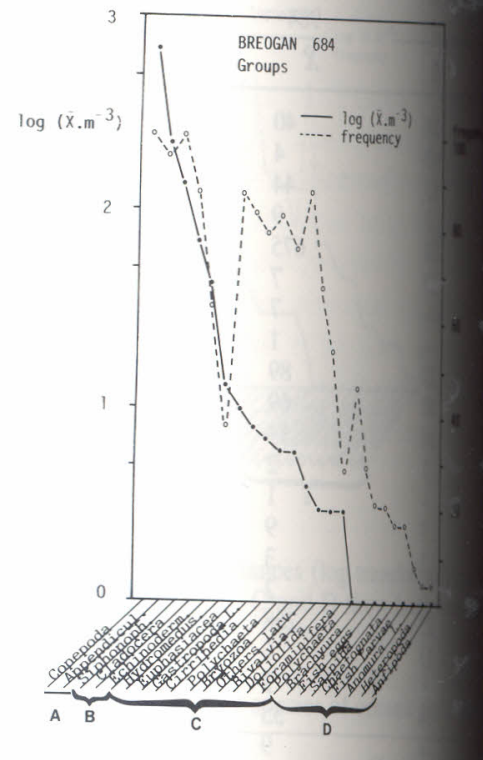

Fig. 4. Main abundances (log transformed BREOGAN 684 and BREOGAN 984. A,

There were 36 species of copep Calanoids made up $74 \%$ of the cop harpacticoids accounted for $9 \%$. clausi (309 ind. $\mathrm{m}^{-3}, \mathrm{SD}=344$ ), Paracalanus parvus (49 ind. $\mathrm{m}^{-3}$ $\left.\mathrm{m}^{-3}, \mathrm{SD}=35\right)$, Pseudocalanus ele helgolandica (33 ind. $\mathrm{m}^{-3}, \mathrm{SD}=$ abundant copepod species were $A$ (675 ind. $\mathrm{m}^{-3}, \mathrm{SD}=733$ ), T.longi spp. $\left(225\right.$ ind $\left.\mathrm{m}^{-3}, \mathrm{SD}=555\right)$. ( P.elongatus ( 89 ind. $\mathrm{m}^{-3}, \mathrm{SD}=$ 94), Clausocalanus spp. (69 ind. $\left.\mathrm{m}^{-3}, \mathrm{SD}=108\right)$, C.helgolandicus ( (44 ind. $\mathrm{m}^{-3}, \mathrm{SD}=123$ ) and 0 .he

Conclusive evidence on which 2 upwelling cannot be obtained unle known prior to upwelling. However their asexual reproduction, are the increases of phytoplankton (Paffe response to upwelling events. The development and one could hypoth 


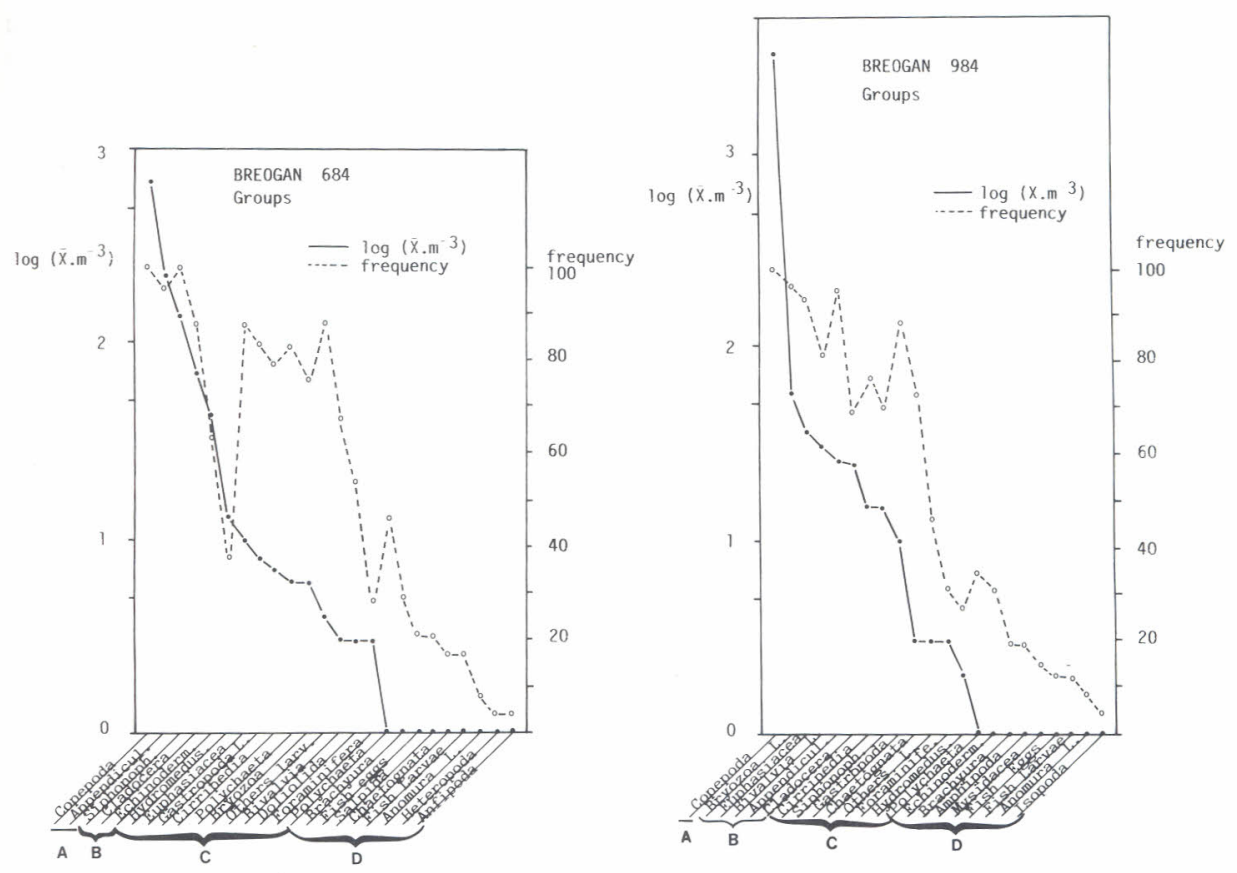

Fig. 4. Main abundances (log transformed) and frequencies of zooplankton groups in the cruises BREOGAN 684 and BREOGAN 984. A, B, C and D show four numerical abundance categories.

There were 36 species of copepods (27 in June and 30 species in September). Calanoids made up $74 \%$ of the copepods species, cyclopoids comprised $17 \%$ and harpacticoids accounted for $9 \%$. In June the dominant species were Acartia clausi (309 ind. $\left.\mathrm{m}^{-3}, \mathrm{SD}=344\right)$, Temora longicornis $\left(63\right.$ ind. $\left.\mathrm{m}^{-3}, \mathrm{SD}=157\right)$, Paracalanus parvus (49 ind. $\mathrm{m}^{-3}, \mathrm{SD}=59$ ), Calanus helgolandicus ( 37 ind. $\left.\mathrm{m}^{-3}, \mathrm{SD}=35\right)$, Pseudocalanus elongatus $\left(37\right.$ ind. $\left.\mathrm{m}^{-3}, \mathrm{SD}=66\right)$, and Oithona helgolandica (33 ind. $\mathrm{m}^{-3}, \mathrm{SD}=45$ ) (Table II). In September, the most abundant copepod species were $A$.clausi $\left(1026\right.$ ind. $\left.\mathrm{m}^{-3}, \mathrm{SD}=1461\right), P$.parvus (675 ind. $\left.\mathrm{m}^{-3}, \mathrm{SD}=733\right)$, T.longicornis $\left(268\right.$ ind. $\left.\mathrm{m}^{-3}, \mathrm{SD}=464\right)$ and Oncaea spp. (225 ind $\left.\mathrm{m}^{-3}, \mathrm{SD}=555\right)$. Other numerically dominant species included P.elongatus ( 89 ind. $\left.\mathrm{m}^{-3}, \mathrm{SD}=121\right)$, Oithona plumifera $\left(49\right.$ ind. $\mathrm{m}^{-3}, \mathrm{SD}=$ 94), Clausocalanus spp. (69 ind. $\left.\mathrm{m}^{-3}, \mathrm{SD}=94\right)$, Centropages typicus (55 ind. $\left.\mathrm{m}^{-3}, \mathrm{SD}=108\right)$, C.helgolandicus $\left(40\right.$ ind. $\left.\mathrm{m}^{-3}, \mathrm{SD}=60\right)$, Calanoides carinatus (44 ind. $\left.\mathrm{m}^{-3}, \mathrm{SD}=123\right)$ and O.helgolandica $\left(34\right.$ ind. $\left.\mathrm{m}^{-3}, \mathrm{SD}=40\right)$ (Figure 5).

Conclusive evidence on which zooplankton species develop in response to upwelling cannot be obtained unless zooplankton abundances on the shelf are known prior to upwelling. However, cladocerans, salps and doliolids, because of their asexual reproduction, are the zooplankters that respond rapidly to sudden increases of phytoplankton (Paffenhofer, 1985) and thus would increase in response to upwelling events. The small copepods also have high rates of development and one could hypothesize that high concentrations of cyclopoids 
Table II. Mean $(\bar{X})$ in $\mathrm{N} \mathrm{m}^{-3}$ and standard deviation (SD) of the copepod species calculated considering the number of samples $(n)$ in which they occurred from a total of 24 samples in BREOGAN 684 and 26 samples in BREOGAN 984

\begin{tabular}{|c|c|c|c|c|c|c|}
\hline & \multicolumn{3}{|l|}{684} & \multicolumn{3}{|l|}{984} \\
\hline & $\bar{X}$ & $\mathrm{SD}$ & $n$ & $\bar{X}$ & SD & $n$ \\
\hline Calanus helgolandicus & 37 & 35 & 24 & 40 & 60 & 22 \\
\hline Calanus tenuicornis & 1 & 0 & 3 & 4 & 2 & 4 \\
\hline Calanoide carinatus & 5 & 6 & 13 & 44 & 123 & 19 \\
\hline Eucalanus spp. & 1 & 0 & 3 & 9 & 13 & 8 \\
\hline Paracalanus parvus & 49 & 59 & 24 & 675 & 733 & 25 \\
\hline Calocalanus stylimeris & 4 & 5 & 14 & 7 & 5 & 15 \\
\hline Calocalanus tenuis & - & - & - & 7 & 9 & 5 \\
\hline Mecynocera clausi & - & - & - & 1 & - & 1 \\
\hline Pseudocalanus elongatus & 37 & 66 & 22 & 89 & 121 & 26 \\
\hline Clausocalanus spp. & 6 & 6 & 10 & 69 & 94 & 24 \\
\hline Ctenocalanus vanus & 10 & 11 & 14 & 14 & 13 & 10 \\
\hline Aetideus armatus & 1 & 1 & 7 & 2 & 2 & 5 \\
\hline Gaetanus minor & - & - & - & 1 & - & 1 \\
\hline Euchaeta hebes & 3 & 4 & 7 & 9 & 9 & 12 \\
\hline Scolecithricella dentata & 1 & 0 & 3 & 3 & 2 & 4 \\
\hline Diaxis durani & - & - & - & 2 & 1 & 2 \\
\hline Temora longicornis & 63 & 157 & 22 & 268 & 464 & 21 \\
\hline Metridia lucens & 5 & 4 & 13 & 6 & 8 & 14 \\
\hline Pleuromamma gracilis & - & - & - & 2 & 1 & 2 \\
\hline Centropages typicus & 3 & 3 & 9 & 55 & 108 & 23 \\
\hline Centropages chierchiae & 6 & 3 & 4 & 9 & 8 & 7 \\
\hline Isias clavipes & 3 & 2 & 4 & 3 & 2 & 4 \\
\hline Candacia armata & 5 & 7 & 20 & 4 & 2 & 13 \\
\hline Anomalocera patersoni & - & - & - & 1 & - & 1 \\
\hline Acartia clausi & 309 & 344 & 24 & 1026 & 1461 & 26 \\
\hline Oithona plumifera & 21 & 39 & 19 & 49 & 94 & 23 \\
\hline Oithona helgolandica & 33 & 45 & 21 & 34 & 40 & 24 \\
\hline Oithona nana & - & - & - & 15 & 15 & 7 \\
\hline Oncaea spp. & 6 & 10 & 19 & 225 & 555 & 25 \\
\hline Corycaeus anglicus & 3 & 4 & 19 & 5 & 6 & 17 \\
\hline Corycaeus furcifer & 1 & - & 1 & 1 & - & 1 \\
\hline Corycaeus typicus & - & - & - & 3 & 1 & 3 \\
\hline Corycaeus spp. & - & - & - & 3 & 2 & 2 \\
\hline Euterpina acutifrons & 3 & 3 & 8 & 4 & 3 & 9 \\
\hline Microsetella norvegica & 1 & - & 1 & 1 & 0 & 2 \\
\hline Clytemenestra rostrata & 2 & 2 & 9 & 2 & 1 & 7 \\
\hline
\end{tabular}

(Oithona and Oncaea) and small calanoids (Acartia and Paracalanus) could serve as indicators of phytoplankton blooms (Paffenhofer, 1980). Mikheyeu (1977) observed that the smaller copepods dominated the center and edges of the upwelling off Peru. His calculations showed that Oncaea, Paracalanus, Oithona and Acartia made up more than $50 \%$ of the biomass. Peterson et al. (1979), found that Calanus marshallae, Pseudocalanus spp., Acartia clausi, A.longiremis and Oithona similis constituted the majority of the zooplankton biomass in an upwelling area off Oregon. With respect to the dominant genera of the copepod community, the results from this Galician project were similar to these two studies.

We can compare the copepod species assemblage in this study with earlier works from the study area (Lakkis, 1967; Alvarez-Ossorio, 1984) and areas near

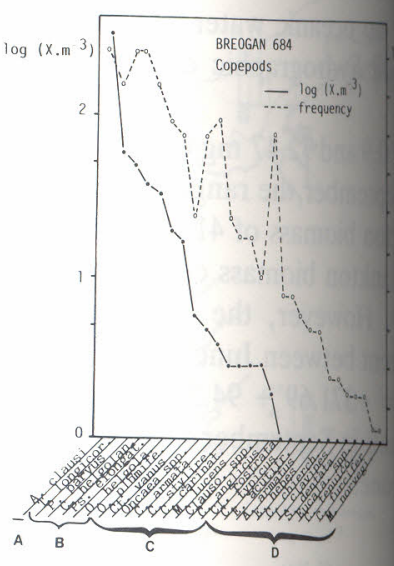

Fig. 5. Main abundances (log transforme both cruises. A, B, C and D show four $\mathrm{n}$

Table III. Indicator species of oceanic an

\begin{tabular}{|c|c|}
\hline & Oceanic sp \\
\hline June & $\begin{array}{l}\text { Calocalanus } \\
\text { Calanus tention } \\
\text { Scolecithricet } \\
\text { Aetideus ann }\end{array}$ \\
\hline September & $\begin{array}{l}\text { Calocalanis } \\
\text { Calocalanus } \\
\text { Scolecithricet } \\
\text { Aetideus arm } \\
\text { Pleuromann }\end{array}$ \\
\hline
\end{tabular}

the continental shelf such as San data). Of those off-shore species, of their samples. The more abund with these other studies; however, from the study conducted by Lak

While the more abundant cone biomass, some of the more rare sp Colebrook et al. (1961) and Corra species for the eastern North At animals are easy to identify and hav types of indicator species, those fo in areas of transition are listed in ?

The oceanic species found in two cold water intrusions. In June whe 

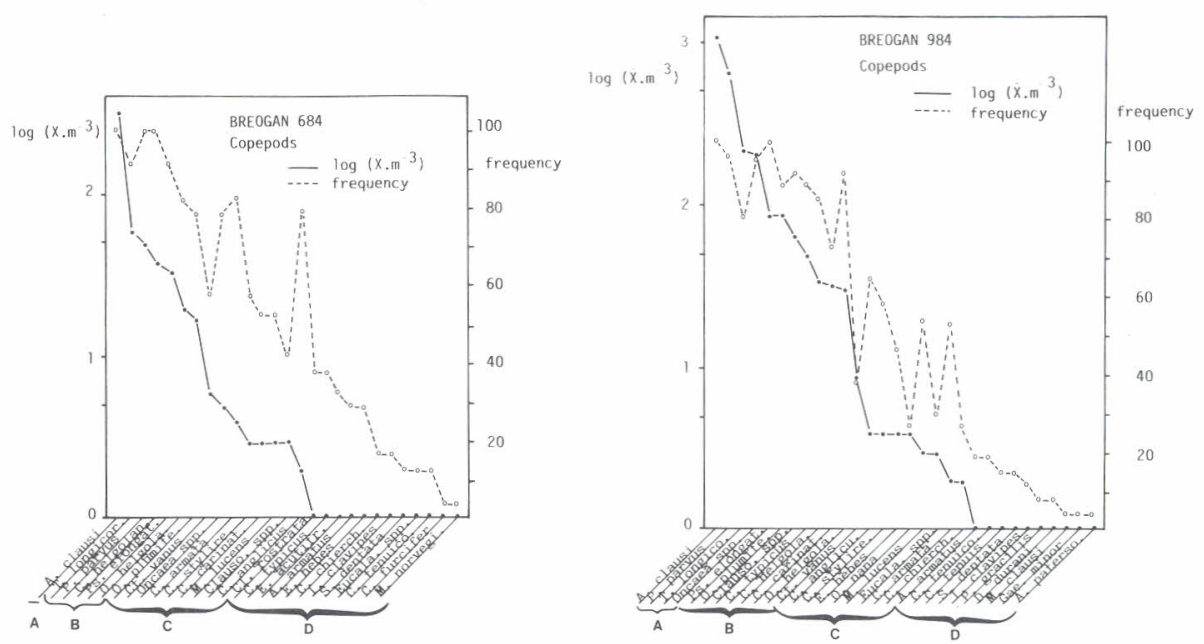

Fig. 5. Main abundances (log transformed) and frequencies of the copepod species assemblage in both cruises. A, B, C and D show four numerical abundance categories.

Table III. Indicator species of oceanic and transition areas in June and September

\begin{tabular}{lll}
\hline & Oceanic species & Transition species \\
\hline June & Calocalanus styliremis & Metridia lucens \\
& Calanus tenuicornis & Centropages typicus \\
& Scolecithricella dentata & Candacia armata \\
September armatus & Euchaeta hebes \\
& Calocalanus styliremis & Metridia lucens \\
& Calocalanus tenuis & Centropages typicus \\
& Scolecithricella dentata & Candacia armata \\
& Pleuromamma gracilis & Euchaeta hebes \\
& & Anomalocera patersoni
\end{tabular}

the continental shelf such as San Ciprian and Burela (J.L.Valdes, unpublished data). Of those off-shore species, only Mecynocera clausi was not present in any of their samples. The more abundant species from our samples were comparable with these other studies; however, there were no quantitative zooplankton data from the study conducted by Lakkis (1967).

While the more abundant copepod species are of importance in terms of biomass, some of the more rare species are indicators of specific water masses. Colebrook et al. (1961) and Corral and Alvarez-Ossorio (1978) list indicator species for the eastern North Atlantic region based on the criteria that the animals are easy to identify and have well established distribution patterns. Two types of indicator species, those found strictly in oceanic areas and those found in areas of transition are listed in Table III.

The oceanic species found in two sampling periods reflect the effect of oceanic cold water intrusions. In June when upwelling occurred, indicator species were 
present at all transects. In September, indicator species were present at the more western transects (Vigo, Arosa and Muros) and absent at the more northern (Vilano, Coruña and Ortegal) transects where no oceanic water had intruded based on chlorophyll (Varela et al., 1987b) and hydrographic data collected (McClain et al., 1986).

In June zooplankton biomass ranged between 0.9 and $72.47 \mathrm{mg} \mathrm{C} \mathrm{m}^{-3}$ with an average of $31.08(\mathrm{SD}=20.59) \mathrm{mg} \mathrm{C} \mathrm{m}^{-3}$. In September the range increased to 6.9-107.7 $\mathrm{mg} \mathrm{C} \mathrm{m}^{-3}$ with an average zooplankton biomass of $41.69 \mathrm{mg} \mathrm{C} \mathrm{m}^{-3}$ $(\mathrm{SD}=26.8)$ (Figure 6). This increase in zooplankton biomass correlated with increases in zooplankton densities (Figure 7). However, the regressions of abundance and biomass were significantly different between June $(Y=99.49+$ $32.88 X ; r=0.78 ; n=24)$ and September $(Y=-371.69+94.20 X ; r=0.81$; $n=26$ ). Approximately twice as many individuals in September resulted in the same zooplankton biomass as compared with June.

\section{Distribution}

Zooplankton abundances $(N+1 \log$ transformed) were similar along the northern and western Galician coast (Figure 8). There were less zooplankton collected from the deeper depths. In June the average abundance for both depths sampled was 1144 ind. $\mathrm{m}^{-3}(\mathrm{SD}=1094)$. However, there was a distinct difference between the zooplankton collected from 0 to $50 \mathrm{~m}\left(1806\right.$ ind. $\mathrm{m}^{-3}$, $\mathrm{SD}=1038)$ and the $50-100 \mathrm{~m}$ area $\left(283\right.$ ind. $\left.\mathrm{m}^{-3}, \mathrm{SD}=198\right)$. In September the average value was 3556 ind. $\mathrm{m}^{-3}(\mathrm{SD}=3126)$, with the $0-50 \mathrm{~m}$ abundance of 4339 ind $\mathrm{m}^{-3}(\mathrm{SD}=2695)$ and the $50-100 \mathrm{~m}$ abundance 601 ind. $\mathrm{m}^{-3}(\mathrm{SD}=$ 346). Thus in both June and September there were 6-7 times more organisms in the surface water as compared with deeper water. Copepods, the major component of the zooplankton, exhibited a similar distribution pattern to total zooplankton abundances with the higher densities in the $0-50 \mathrm{~m}$ region of the water column. In September the highest copepod abundance were in the upwelling area and the inshore stations of the western transects.

The species composition between the two depth ranges sampled was similar, but the percentage composition of the species varied. Species diversity is greater in the deeper waters than in the shallow region (Figure 9). The copepods, A.clausi, P.parvus and T.longicornis were dominant in the surface waters.

Higher zooplankton abundances in the surface waters was also reflected in higher zooplankton biomass. In June the average biomass value for the upper water column was $43.01 \mathrm{mg} \mathrm{C} \mathrm{m}^{-3}(\mathrm{SD}=20.59)$. Biomass in the deeper part of the water column was $11.81 \mathrm{mg} \mathrm{C} \mathrm{m}^{-3}(\mathrm{SD}=9.18)$. In September zooplankton biomass was similar with an average value of $48.66 \mathrm{mg} \mathrm{C} \mathrm{m}^{-3}(\mathrm{SD}=26.39)$ in the upper water column and $21.07 \mathrm{mg} \mathrm{C} \mathrm{m}^{-3}(\mathrm{SD}=14.9)$ in the lower water column. The upper to lower water column biomass ratio was 4:1 in June and 2:1 in September. This is less than abundance ratios (6:1 and 7:1 respectively), suggesting a higher concentration of small animals in the upper water column. As stated previously, the small copepods A.clausi, P.parvus and T.longicornis comprised a large portion of the zooplankton community in the surface water.

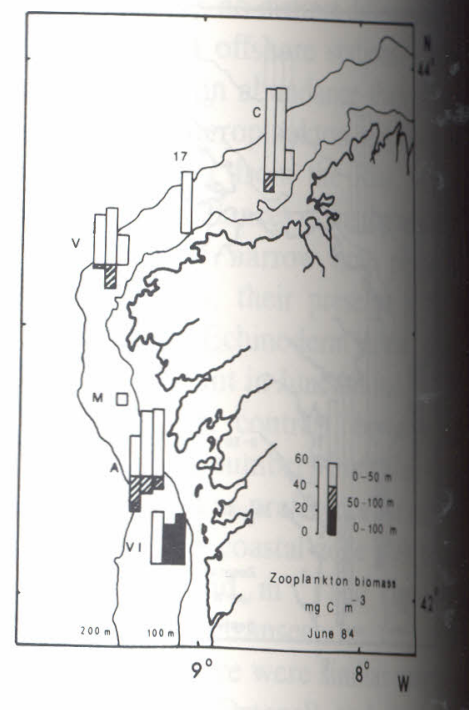

Fig. 6. Zooplankton biomass $\left(\mathrm{mg} \mathrm{Cm}^{-3}\right.$

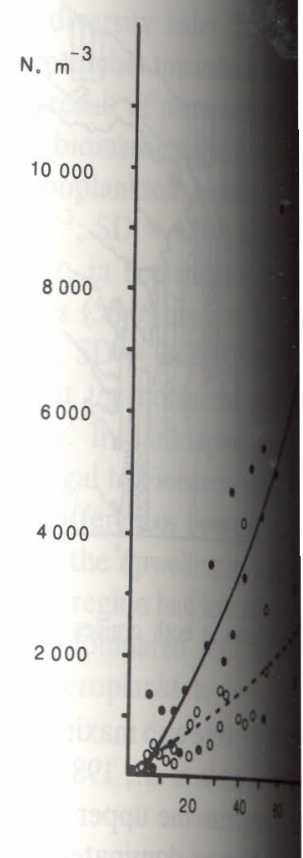

Fig. 7. Linear regressions of abundance an 

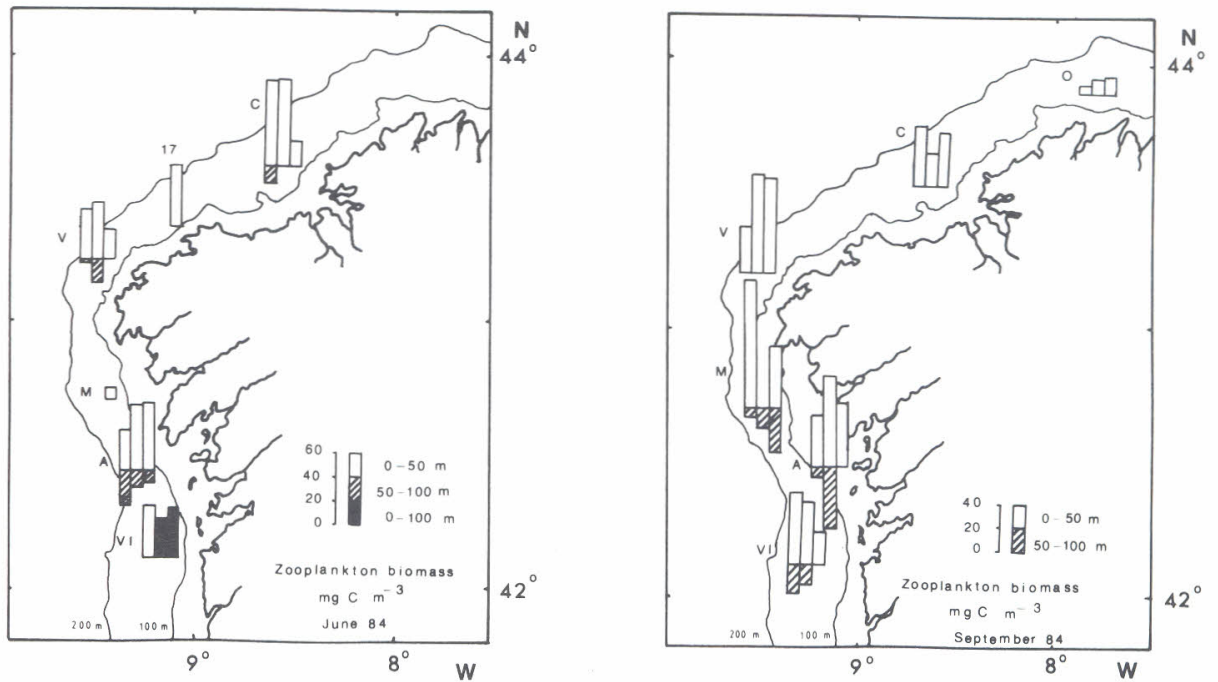

Fig. 6. Zooplankton biomass $\left(\mathrm{mg} \mathrm{C} \mathrm{m}^{-3}\right)$ distribution at the different depths (m) for both cruises.

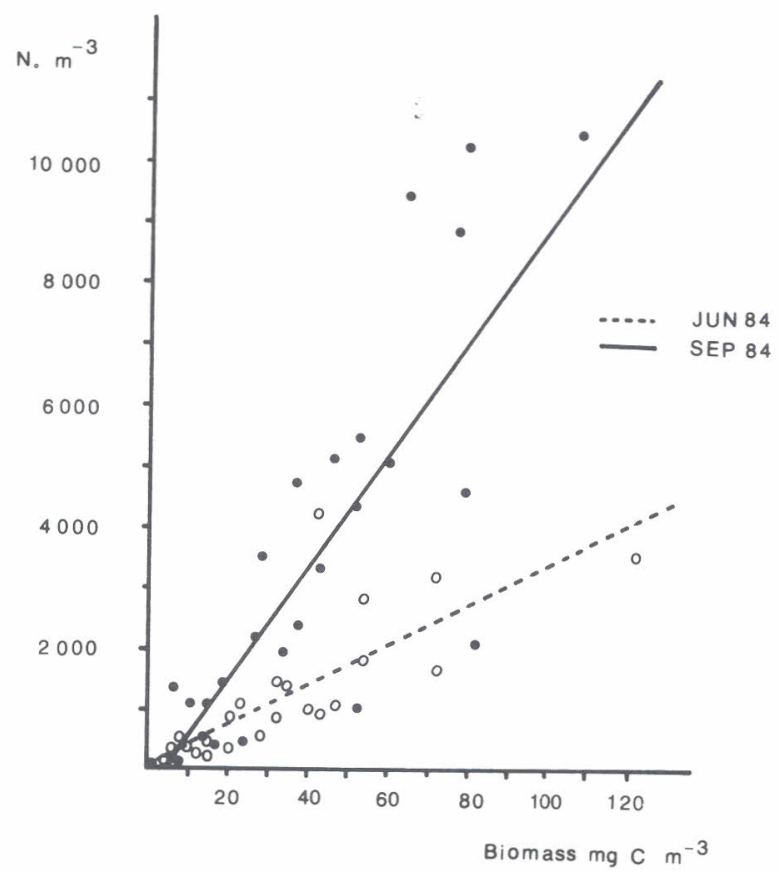

Fig. 7. Linear regressions of abundance and biomass in June $(\bigcirc)$ and September $(0)$. 

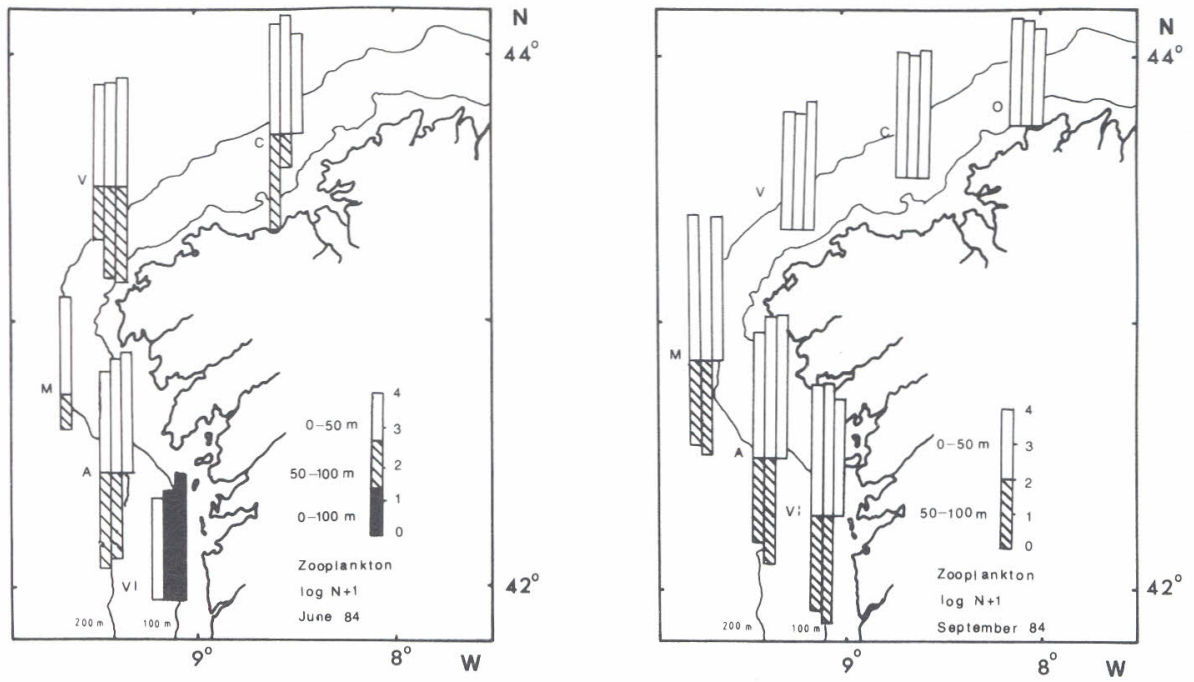

Fig. 8. Zooplankton abundances (log transformed) distribution in the sampled area during the cruises BREOGAN 684 and BREOGAN 984
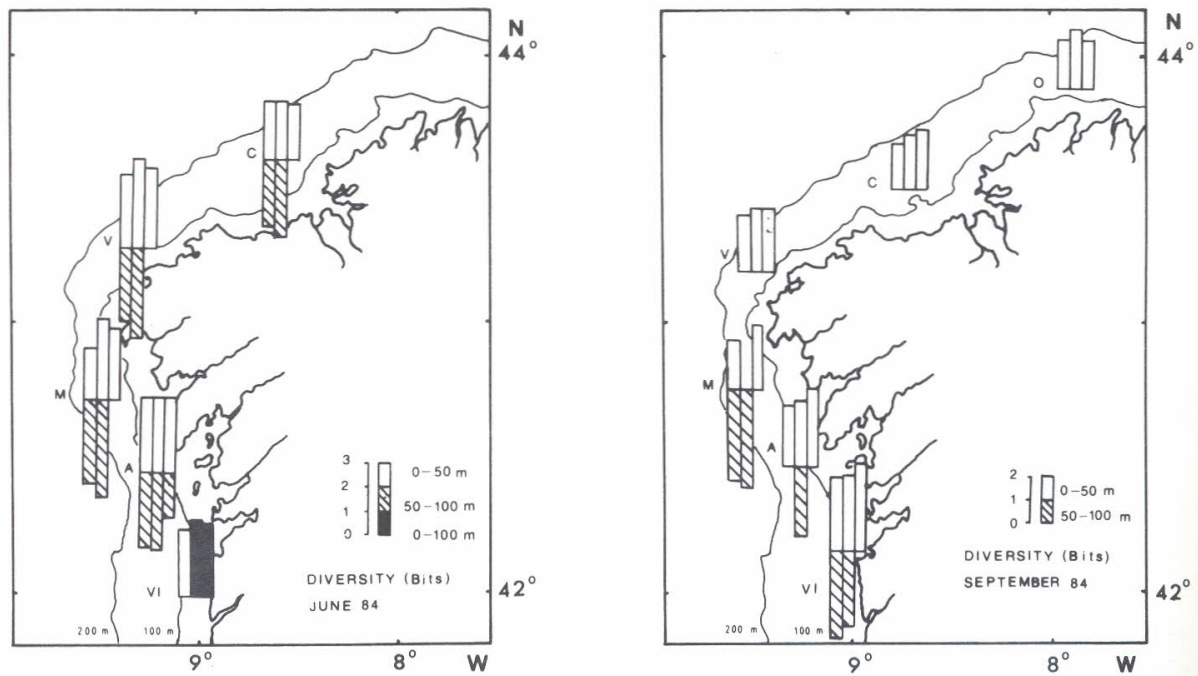

Fig. 9. Diversity index distribution in the sampled area in both cruises BREOGAN 684 and BREOGAN 984.

Both phytoplankton biomass and productivity were also maximum in the surface $50 \mathrm{~m}$ at the Galician coast (Estrada, 1984; Varela et al., 1987a, 1987b).

Considering all these factors, we can categorize the upper water column as a region of high zooplankton abundance and biomass dominated by a few number of small copepod species. The deeper water in contrast was dominated by large species of lower abundances and higher diversity. 
There was no distinct difference in total zooplankton abundance between the inshore and offshore stations. However, in June inshore stations had higher meroplankton abundance than offshore stations. This difference in the contribution of meroplankton was likely the result of onshore-offshore outflow of coastal water from the Rias. In September, the Vigo transect also had the highest abundances of meroplankton in relation to the other transects sampled.

Given the narrow time period for reproduction of the various benthic invertebrates, their presence in the meroplankton varied between June and September. Echinoderm larvae, primarily distributed in the neritic areas, were more abundant in June ( 69 ind. $\left.\mathrm{m}^{-3}, \mathrm{SD}=188\right)$ than in September $\left(5\right.$ ind. $\mathrm{m}^{-3}$, $\mathrm{SD}=4$ ). In contrast, bryozoan and bivalve larvae (larger than $200 \mu \mathrm{m}$ ) increased in numbers from June to September. Bryozoan abundances did not indicate a clear preference for neritic areas. However bivalve larvae were only found in the coastal zone with highest abundances at the inshore stations of Arosa (277 ind $\mathrm{m}^{-3}$ ) and Vigo (140 ind. $\mathrm{m}^{-3}$ ), with no larvae present at the Cape Ortegal transect.

In June there were similar zooplankton abundances at the northern (Vilano, Coruña and Ortegal) and the western transects (Vigo, Arosa and Muros). However, in September there was a distinct difference in these two regions (Figure 8), with abundances of 2812 ind. $\mathrm{m}^{-3}(\mathrm{SD}=1590)$ in the northern areas and higher abundances of 6036 ind. $\mathrm{m}^{-3}(\mathrm{SD}=2648)$ in the western region. In both June and September the average number of species was higher in the western region ( 30 species) as compared with the northern region ( 25 species). However, the diversity index (Figure 9) is about the same in June for all transects. In September this index is highest at the western transects. This higher diversity is the result of meroplankton being advected from the Rias.

Zooplankton biomass exhibited a similar pattern as abundance. For example, during June zooplankton biomass was roughly the same in the northern (35.02 $\left.\mathrm{mg} \mathrm{C} \mathrm{m}^{-3} ; \mathrm{SD}=17.03\right)$ and western regions $\left(33.57 \mathrm{mg} \mathrm{C} \mathrm{m}^{-3} ; \mathrm{SD}=\right.$ 11.49). However, in September there was higher zooplankton biomass in the western transects $\left(58.69 \mathrm{mg} \mathrm{C} \mathrm{m}^{-3}, \mathrm{SD}=22.6\right)$ than in the northern stations (39.7 $\mathrm{mg} \mathrm{C} \mathrm{m}^{-3}, \mathrm{SD}=26.25$ ) (Figure 6).

It is likely that the horizontal distribution of zooplankton is related to the upwelling events. In June upwelling occurred over the entire Galician shelf (from Cape Ortegal to Finisterre and in the south of the Rias Bajas) and we did not find major differences between the northern and the western transects. In September when the upwelling was apparent only at the Ria de Vigo we found that the northern region had less zooplankton abundance, biomass and diversity index values as compared with the western region which also had highest abundances of meroplankton.

\section{Conclusions}

As a summary of our work during cruises BREOGAN 684 and BREOGAN 984 we can conclude the following. 
June

The abundance of cladocerans, salps and doliolids in the zooplankton assemblage suggest that we were working in the beginning of an upwelling event. The distribution of the indicator species suggest that there were oceanic cold water intrusions over the entire Galician shelf. The zooplankton community was dominated by copepods (64\%), with A.clausi, T.longicornis, P.parvus, C.helgolandicus, Ps.elongatus and $O$.helgolandica all having abundances higher than 20 ind. $\mathrm{m}^{-3}$. Zooplankton biomass as well as the abundances did not have a clear inshore-offshore distribution. Meroplankton were located mainly in the inshore stations of the western region which was likely the result of outflow of coastal water from the Rias. The upper to lower water column ratios were $4: 1$ for zooplankton biomass and 6:1 for zooplankton abundances.

\section{September}

There was a complete absence of doliolids, low abundances of cladocerans but high abundances of Oncaea spp. The hydrographical data suggested that upwelling was occurring only at the Ria de Vigo and its intensity decreased towards the north of the Rias and offshore. Oceanic species of copepods were present at the western region (Vigo, Arosa and Muros) and absent in the northern region (Vilano, Coruña and Ortegal) where no oceanic water had intruded. Copepods were the most abundant group of the zooplankton $(>90 \%)$. A.clausi, P.parvus, T.longicornis and Oncaea spp. abundances were higher than 200 ind. $\mathrm{m}^{-3}$. As in June, neither the biomass nor the abundance had a clear inshore-offshore distribution. However, meroplankton abundance was highest in the inshore stations of the western region. The upper to lower water column biomass ratio was $2: 1$, which was much less than the abundance ratio of $7: 1$. These ratios suggest a higher concentration of small animals in the surface layer of the water column.

\section{Acknowledgements}

We would like to thank all those who helped with this project, especially the crew of the $\mathrm{R} / \mathrm{V}$ Cornide Saavedra. This project was funded through the US-Spain Joint Committee for Scientific and Technological Cooperation (project number CCA-8309023).

\section{References}

Alcaraz,M. (1977) Ecologia, competencia y segregacion en especies congeneres de Copepodos (Acartia), PhD Thesis, University of Barcelona.

Alvarez-Ossorio,M. (1977) Estudio de la comunidad de copepodos de la Ria de Muros (España) en noviembre 1975. Bol. Inst. Esp. Oceanogr., 233, 75-108.

Alvarez-Ossorio,M. (1984) Primeros datos sobre el zooplancton de la plataforma gallega. Bol. Inst. Esp. Oceanogr., 1(2), 31-47.

Blanton,J.O., Atkinson,L.P., Fernandez de Castillejo,F. and Lavin,A. (1982) Coastal upwelling off the Rias Bajas, Galicia, NW Spain. I: Hydrographic studies. Paper presented at the ICES Symposium on Biological Productivity of Continental Shelves in the Temperate Zone of the North Atlantic, Kiel, 2-5 March 1982.
Colebrook,J.M., Glover,R.S. and Rob Contributions towards a plankton at Introduction. Bull. Mar. Ecol.,5,

Corral,J. and Alvarez-Ossorio,M. Composicion y distribucion de las 133-163.

Estrada,M. (1984) Phytoplankton distr Spain). J. Plankton Res., 6, 417-43

Fraga,F. (1967) Hidrografia de la Riad Inv. Pesq., 31, 145-159.

Fraga,F. (1981) Upwelling off the $G$ Upwelling. American Geophysical l

Fraga,F., Mouriño,C. and Manriquey junio-octubre. Res. Exp. Cient. $B(C$ Gomez-Gallego,J.G. (1971) Estudio verano. Bol. Inst. Esp. Oceanogr.,

Gomez-Gallego,J.G. (1975) Estudio invierno. Bol. Inst. Esp. Oceanogr

Lakkis,S. (1967) Distribution et fluct la Manche et le Golfe de Gascone de

Margalef,R., Duran,M. and Saiz,F. ( marzo de 1954. Inv. Pesq., 2, 85-12

Margalef,D.R. (1957) La teoria de Barcelona, 23, 373-449.

McClain,C.R., Chao,S., Atkinson,L. upwelling in the vicinity of Cape Fin

Mikheyev, V.N. (1977) Structural chara region. Oceanology (USSR), 17, 462

Otto,L. (1975) Oceanography of the R Mededelingen en Verhandelingen,

Paffenhofer,G.A. (1980) Zooplankton Onslow bay, North Carolina. Bull.

Paffenhofer,G.A. (1985) The abundanc of the United States. In American $\mathrm{G}$ the Southeastern U.S. Continental Sh

Perez,A. and Roman,G. (1979) Estudic de Arosa. II: Crecimiento, mortalid $\mathrm{V}(\mathbf{2 6 7}), 23-41$.

Peterson,W.T., Miller,C.B. and Hutc populations in the Oregon upwelling

Roman,M.R., Gauzens,A.L. and Cowles microzooplankton and mesozooplanktor Res., 32(9), 1007-1022.

Spohr, N. and Corral,J. (1976) Primeros la Ria de Muros (NW de España). Bol

Tenore,K.R., Boyer,L.F., Cal,R.M., Hanson, R.B., Iglesias,J., Krom,M., Rhoads,D.C., De Santiago,G., Tie upwelling in the Rias Bajas, NW Spain Muros. J. Mar. Res., 40, 701-772

Varela,M., Cabanas,J., Campos,M.J. Castillejo,F. and Diaz del Rio,G. ( plataforma de Galicia durante la ca Oceanogr. , 4, 75-94.

Varela,M., Campos,M.J., Cabanas,J. Composicion y distribucion del fito BREOGAN-984 (septiembre-octubre

Wiebe,P.H., Boyd,S.H. and Cox,J.L. volume, wet weight, dry weight and

Received on August 29, 1989; accepted on 
Colebrook,J.M., Glover,R.S. and Robinson,G.A. (1961) Continuous plankton records, 1948-1956: Contributions towards a plankton atlas of the north-eastern Atlantic and the North Sea. General Introduction. Bull. Mar. Ecol., 5, 67-80.

Corral,J. and Alvarez-Ossorio,M. (1978) El zooplancton de la Ria de Arosa (NW de España): Composicion y distribucion de las comunidades en un ciclo anual. Bol. Inst. Esp. Oceanogr., 265, $133-163$.

Estrada,M. (1984) Phytoplankton distribution and composition off the coast of Galicia (northwest of Spain). J. Plankton Res., 6, 417-434.

Fraga,F. (1967) Hidrografia de la Ria de Vigo con especial referencia a los compuestos de nitrogeno. Inv. Pesq., 31, 145-159.

Fraga,F. (1981) Upwelling off the Galician coast, Northwest Spain. In Richards,F.A. (ed.), Coastal Upwelling. American Geophysical Union, Washington DC, pp. 176-182.

Fraga,F., Mouriño,C. and Manriquez,M. (1982) Las masas de agua en la costa de Galicia: junio-octubre. Res. Exp. Cient. B/O Cornide, 10, 51-77.

Gomez-Gallego,J.G. (1971) Estudio de las condiciones oceanograficas en la Ria de Arosa, en verano. Bol. Inst. Esp. Oceanogr., 147, 1-39.

Gomez-Gallego,J.G. (1975) Estudio de las condiciones oceanograficas en la Ria de Arosa, en invierno. Bol. Inst. Esp. Oceanogr., 185, 1-53.

Lakkis,S. (1967) Distribution et fluctuations quantitatives des copepodes et du phytoplancton dans la Manche et le Golfe de Gascone de 1958 a 1965. PhD Thesis, Fac. Scien. Univ. Paris.

Margalef,R., Duran,M. and Saiz,F. (1955) El fitoplancton de la Ria de Vigo de enero de 1953 a marzo de 1954. Inv. Pesq., 2, 85-129.

Margalef.D.R. (1957) La teoria de la informacion en ecologia. Mems. R. Acad. Cienc. Artes, Barcelona, 23, 373-449.

McClain,C.R., Chao,S., Atkinson,L.P., Blanton,J.O. and Castillejo,F. (1986) Wind-driven upwelling in the vicinity of Cape Finisterre, Spain. J. Geophy. Res., 91, 8470-8486.

Mikheyev,V.N. (1977) Structural characteristics of the zoocoenosis in the Peruvian coastal upwelling region. Oceanology (USSR), 17, 462-465 (Engl. transl.).

Otto,L. (1975) Oceanography of the Ria de Arosa (NW Spain), Koninklijk Ned. Meteoro. Inst. Mededelingen en Verhandelingen, 96.

Paffenhofer,G.A. (1980) Zooplankton distribution as related to summer hydrographic conditions in Onslow bay, North Carolina. Bull. Mar. Sci., 30, 819-832.

Paffenhofer,G.A. (1985) The abundance and distribution of zooplankton on the Southeastern Shelf of the United States. In American Geophysical Union, Washington DC (ed.), Oceanography of the Southeastern U.S. Continental Shelf, pp. 104-117.

Perez,A. and Roman,G. (1979) Estudio del mejillon y su epifauna en los cultivos flotantes de la ria de Arosa. II: Crecimiento, mortalidad y produccion del mejillon. Bol. Inst. Esp. Oceanogr., $\mathbf{V}(\mathbf{2 6 7}), 23-41$

Peterson,W.T., Miller,C.B. and Hutchinson,A. (1979) Zonation and maintenance of copepod populations in the Oregon upwelling zone. Deep-Sea Res., 26A, 467-494.

Roman,M.R., Gauzens,A.L. and Cowles,T.J. (1985) Temporal and spatial changes in epipelagic microzooplankton and mesozooplankton biomass in warm-core Gulf Stream ring 82-B. Deep-Sea Res., 32(9), 1007-1022.

Spohr,N. and Corral,J. (1976) Primeros datos sobre la sistematica y la ecologia de los copepodos de la Ria de Muros (NW de España). Bol. Inst. Esp. Oceanogr., 206, 1-25.

Tenore,K.R., Boyer,L.F., Cal,R.M., Corral,J., Garcia,C., Gonzalez,N., Gonzalez-Gurriaran,E., Hanson,R.B., Iglesias,J., Krom,M., Lopez-Jamar,E., McClain,J., Pamatmat,M.M., Perez,A., Rhoads,D.C., De Santiago,G., Tietjen,J., Westrich,J, and Windom,H.L. (1982) Coastal upwelling in the Rias Bajas, NW Spain: contrasting the benthic regimes of the Rias of Arosa and Muros. J. Mar. Res., 40, 701-772.

Varela,M., Cabanas,J. Campos,M.J. Penas,E., Sanchez,J, Larrañaga,A., Fernandez de Castillejo,F. and Diaz del Rio,G. (1987a) Composicion y distribucion del fitoplancton en la plataforma de Galicia durante la campaña BREOGAN-684 (junio de 1984). Bol. Inst. Esp. Oceanogr., 4, 75-94.

Varela,M., Campos,M.J., Cabanas,J., Fernandez de Castillejo,F. and Diaz del Rio,G. (1987b) Composicion y distribucion del fitoplancton en la plataforma de Galicia durante la campaña BREOGAN-984 (septiembre-octubre de 1984). Bol. Inst. Esp. Oceanogr., 4, 95-106.

Wiebe,P.H., Boyd,S.H. and Cox,J.L. (1975) Relationships between zooplankton displacement volume, wet weight, dry weight and carbon. Fish. Bull., 73, 777-786.

Received on August 29, 1989; accepted on December 12, 1989 